\title{
Nutritional Content and Characteristics of Antimicrobial Compounds from Fermented Oil Palm Fronds (Elaeis guineensis Jacq.)
}

\author{
Dewi Febrina ${ }^{1}$, Rahmi Febriyanti ${ }^{1}$, Syukria Ikhsan Zam ${ }^{2 *}$, Zumarni ${ }^{1}$, Jepri Juliantoni ${ }^{1}$, \\ Abdul Fatah 1 \\ ${ }^{1}$ Department of Animal Science, Faculty of Agriculture and Animal Sciences, State Islamic University of Sultan \\ Syarif Kasim Riau, Pekanbaru 28293, Indonesia \\ ${ }^{2}$ Department of Agrotechnology, Faculty of Agriculture and Animal Sciences, State Islamic University of Sultan \\ Syarif Kasim Riau, Pekanbaru 28293, Indonesia
}

Article history:

Submission June 2019

Revised September 2019

Accepted November 2019

*Corresponding author:

E-mail:

syukria.ikhsan.zam@uin-suska.ac.id

\begin{abstract}
This research was conducted to determine physical quality, the nutritional quality and characteristics of antimicrobial compounds from fermented oil palm fronds (FOPF). This research was carried out using a Complete Randomized Design with 4 treatments and 4 replications. The following treatments were performed by the addition of different additives namely: $10 \%$ poultry manure, $10 \%$ cow feces, $5 \%$ urea and $5 \%$ molasses. All treatments were extracted in stages using n-hexane, ethyl acetate and methanol. The observed parameters were physical quality ( $\mathrm{pH}$, aroma, color, and texture), nutritional quality (neutral detergent fiber (NDF), acid detergent fiber (ADF), hemicellulose, cellulose and lignin), yield of extract, class of bioactive compounds and the antimicrobial activity test of extracted compounds. The data were analyzed using a one-way analysis of variance and differences between treatments were tested using Duncan's multiple range test. The addition of different additives has a very significant effect $(\mathrm{P}<0.01)$ on the lignin content; significant effect $(\mathrm{P}<0.05)$ on $\mathrm{pH}$, aroma, color and texture; and no effect on the content of NDF, ADF, hemicellulose and cellulose. The highest yield of extract was obtained from methanol extract with the addition of poultry manure. The methanol extract on the addition of poultry manure and urea were identified as compounds in the steroid, tannin and phenolic classes. The highest antimicrobial activity test against Escherichia coli $(12.83 \mathrm{~mm})$ was obtained from FOPF extract (1\%) with addition of poultry manure, while highest antimicrobial activity test against Staphylococcus aureus (11.67 $\mathrm{mm}$ ) was obtained from FOPF extract (4\%) with addition of molasses. The conclusion of this research was FOPF with addition of poultry manure provides good physical quality, nutritional quality and can inhibit the growth of E. coli and S. aureus at a concentration of $1 \%$.
\end{abstract}

Keywords: Nutritional content, Antimicrobial, Oil palm fronds

\section{Introduction}

The utilization of oil palm plantation waste such as oil palm fronds as feed is still limited due to the high lignin content [1, 2]. Physical-chemical-biological and combination treatments and the addition of additives on the fermentation process aim to break down lignocellulose and lignohemicellulose bonds and increase nutrient digestibility $[3,4,5]$. 
Palm oil fronds have antimicrobial activity [6]. Methanol extract from palm oil leaves contains tannin, alkaloids, saponins, terpenoids and flavonoids [7]; and toxicity tests on shrimp and rats showed that palm oil leaf extract is safer for consumption and recommended as a natural product [8]. This study aims to determine physical quality, the nutritional quality, and characteristics of antimicrobial compounds from fermented oil palm fronds.

\section{Materials and Methods}

The research was conducted in June-November 2017, at the Laboratory of Nutrition and Chemistry at the Faculty of Agriculture and Animal Sciences of State Islamic University of Sultan Syarif Kasim Riau Indonesia, Biotechnology Research Center of the Indonesian Sciences Institute Indonesia and Laboratory of Biota Sumatra Andalas University.

The study was conducted through two (2) stages: namely fermentation of oil palm frond based on Febrina [9] modified with different additive $(10 \%$ poultry manure, $10 \%$ cow feces, $5 \%$ urea and $5 \%$ molasses) using a Completely Randomized Design 4 treatment with 4 replications. Fermentation process for 21 days. The data were analyzed using a one-way analysis of variance and differences between treatments were tested using Duncan's Multiple Range Test. The observed parameters were physical quality tests include $\mathrm{pH}$, aroma, color and texture and nutritional quality including the content of NDF, ADF, hemi cellulose, cellulose, and lignin based on Van Soest analysis using the FOSS Fibertec system. The second stage is multilevel maceration and extraction using methanol, ethyl acetate and n-hexane solvents. Phytochemical screening based on Franswort [10] and the antibacterial activity test of oil palm fronds extract based on Handayani et al. [11].

\section{Result and Discussion}

\section{The Effect of different additives on the physical quality of FOPF}

The addition of different additives has a significant effect $(\mathrm{P}<0.05)$ on the physical quality of FOPF including $\mathrm{pH}$, aroma, color and texture (Table 1). The lowest of $\mathrm{pH}(5.18)$ in treatment $\mathrm{A}$ is related to the availability of carbohydrates and the production of lactic acid bacteria. The same results were seen in treatment $\mathrm{D}$ with a $\mathrm{pH}$ of 5.28. Ad- dition of poultry manure and molasses on fermentation oil palm frond aims as a source of additive which can trigger the growth of lactic acid bacteria to produce lactic acid. Increased production of lactic acid will reduce $\mathrm{pH}$ and inhibit the growth of pathogenic bacteria. Ozduven et al. [12] stated that $\mathrm{pH}$ is associated with lactic acid produced during the fermentation process which can inhibit the growth of pathogenic microbes. Oil palm fronds which are fermented with molasses produce $\mathrm{pH}$ 3.93 [3].

The process of ammonization of oil palm fronds using urea will produce the highest $\mathrm{pH}$ of 7.60 which is alkaline. The same results were reported by Zahari et al. [3], the process of ammonization of oil palm fronds using urea resulting in a $\mathrm{pH}$ of 7.38. In the process of ammonization with urea will break down into ammonium ions so that the ammonization product is alkaline. Laura and Paolo [13] state that urea will break down into ammonium ions, which are alkaline and ammonization processes can break down glycoside bonds [14] so that the oil palm fronds can be degraded by rumen microbes.

In treatment A produces an aroma score of 3 with acid criteria. It has been shown that the fermentation process is going well as indicated by acid production. Aroma is related to the production of lactic acid and $\mathrm{pH}$. It can be seen in Table 1 the addition of poultry manure to oil palm fronds fermentation resulting in the lowest $\mathrm{pH}$ (5.18) so that the products are acidic.

Treatment A, B and D produces a color that is not different $(P>0.05)$, which is natural green or yellowish green with score of 3-3.03. Good quality silage will produce colors that are not different from the original material [15]. The occurrence of color changes from green to yellowish green indicated the anaerobic phase oxygen has run out of carbohydrates. Then it will produce $\mathrm{CO}_{2}, \mathrm{H}_{2} \mathrm{O}$ and heat. The heat produced causes a change in color from green to yellowish green.

Treatment A will produce softer textures with score 2 . This shows that the addition of the poultry manure to the fermentation process can support the growth of lactic acid bacteria to produce lactic acid. Optimal production of lactic acid will reduce $\mathrm{pH}$ so that it inhibits the growth of pathogenic bacteria. This low $\mathrm{pH}$ also supports the production of lignase enzymes which function to break down lignocellulose and lignohemicellulose thereby re- 
Table 1. The effect of different additives on the physical quality of FOPF

\begin{tabular}{|c|c|c|c|c|c|c|c|c|}
\hline \multirow{3}{*}{ Treatment } & \multicolumn{8}{|c|}{ Physical quality } \\
\hline & \multicolumn{2}{|l|}{$\mathrm{pH}$} & \multicolumn{2}{|c|}{ Aroma } & \multicolumn{2}{|c|}{ Color } & \multicolumn{2}{|c|}{ Texture } \\
\hline & Value & Notes & Value & Notes & Value & Notes & Value & Notes \\
\hline A & $5.18^{\mathrm{a}} \pm 0.10$ & Acid & $3.00^{\mathrm{b}} \pm 0.00$ & Acid & $3.03^{\mathrm{a}} \pm 0.05$ & $\begin{array}{l}\text { Yellowish } \\
\text { Green }\end{array}$ & $2.00^{\mathrm{a}} \pm 0.00$ & Rather Soft \\
\hline B & $5.52^{\mathrm{b}} \pm 0.20$ & Acid & $4.00^{\mathrm{c}} \pm 0.00$ & $\begin{array}{l}\text { More } \\
\text { Acidic }\end{array}$ & $3.00^{\mathrm{a}} \pm 0.00$ & $\begin{array}{l}\text { Yellowish } \\
\text { Green }\end{array}$ & $3.00^{b} \pm 0.00$ & Soft \\
\hline C & $7.60^{c} \pm 0.14$ & Base & $2.03^{\mathrm{a}} \pm 0.05$ & $\begin{array}{l}\text { Non- } \\
\text { acidic }\end{array}$ & $4.03^{b} \pm 0.05$ & $\begin{array}{l}\text { Brownish } \\
\text { Green }\end{array}$ & $3.03^{b} \pm 0.05$ & Soft \\
\hline D & $5.28^{\mathrm{ab}} \pm 0.21$ & Acid & $5.00^{\mathrm{d}} \pm 0.00$ & $\begin{array}{c}\text { Very } \\
\text { Acidic }\end{array}$ & $3.00^{\mathrm{a}} \pm 0.00$ & $\begin{array}{l}\text { Yellowish } \\
\text { Green }\end{array}$ & $3.00^{\mathrm{b}} \pm 0.00$ & Soft \\
\hline
\end{tabular}

Table 2. The effect of different additive on fiber fraction of FOPF

\begin{tabular}{cccccc}
\hline \multirow{2}{*}{ Treatment } & \multicolumn{5}{c}{ Fiber Fraction (\%) } \\
\cline { 2 - 6 } & NDF & ADF & Hemicellulose & Cellulose & Lignin \\
\hline A & $73.34 \pm 3.68$ & $51.81 \pm 4.82$ & $21.52 \pm 6.07$ & $28.54 \pm 3.36$ & $19.94^{\mathrm{a}} \pm 1.47$ \\
B & $75.39 \pm 2.03$ & $55.03 \pm 4.23$ & $20.35 \pm 4.46$ & $29.57 \pm 3.09$ & $23.15^{\mathrm{b}} \pm 0.96$ \\
C & $73.83 \pm 1.01$ & $53.30 \pm 3.43$ & $20.51 \pm 4.30$ & $31.55 \pm 1.99$ & $21.57^{\mathrm{a}} \pm 1.58$ \\
D & $74.98 \pm 3.52$ & $54.04 \pm 4.48$ & $20.93 \pm 6.63$ & $31.70 \pm 4.27$ & $22.41^{\mathrm{b}} \pm 1.22$ \\
\hline
\end{tabular}

Note: $\mathrm{A}=$ FOPF with the addition of poultry manure

$\mathrm{B}=\mathrm{FOPF}$ with the addition of cow feces

$\mathrm{C}=\mathrm{FOPF}$ with the addition of urea

$\mathrm{D}=\mathrm{FOPF}$ with the addition of molasses

$\mathrm{a}, \mathrm{b}$, and c mean with different superscript differ $(\mathrm{p}<0.05)$

ducing lignin content. It is seen that treatment A produced the lowest lignin content of $19.94 \%$. The release of lignin from cellulose and hemicellulose causes fermented products to have a softer texture.

\section{The Effect of different additive on fiber fraction of FOPF}

The addition of different additive had no effect ( $P>0.05$ ) on the content of NDF, ADF, hemicellulose and cellulose but had a very significant effect $(\mathrm{P}<0.01)$ on the lignin content (Table 2). Rahman et al. [4] reported there was a decrease in the lignin content of oil palm fronds in the fermentation process using white rot fungi.

Lignin is a part of plant cell walls which consists of very complex and difficult to digest bonds. The high content of lignin in the feed will reduce its digestibility. The lignin content of oil palm fronds is $30.18 \%$ [2]. One of the purposes of processing feed through ammonization and fermentation in oil palm fronds is to reduce the lignin content. The addition of different additive gave a very significant effect $(\mathrm{P}<0.01)$ on the lignin content of FOPF. The lowest lignin content in treatment A (19.94\%) was not significantly different (P >
0.05) compared to treatment $C(21.57 \%)$ but was very significant $(\mathrm{P}<0.01)$ lower treatment $\mathrm{B}$ (23.15\%) and treatment D (22.41\%).

The lowest lignin content in treatment $\mathrm{A}$ (19.94\%) allegedly in the oil palm frond fermentation using poultry manure will produce higher lignase and urease enzymes than other treatments. The lignase enzyme is an extracellular enzyme that functions to degrade lignin and urease to break down urea into ammonia. Poultry manure also functions as a source of urease which will break down urea into ammonia and $\mathrm{CO}_{2}$. The high $\mathrm{N}$ content in poultry manure, which is $3.63-5.30 \%$ with C/N ratio 5.8-7.6 [16], causes high urease activity so that the addition of poultry manure as a source of additive in palm frond fermentation can reduce lignin content. Thambirajah et al. [17] there is a positive correlation between the nitrogen content of poultry manure and the nutritional content of oil palm empty fruit bunches fermented with poultry manure. The addition of $15 \%$ poultry manure in ammoniated rice straw can reduce fermentation time from 20 days to 5 days. 


\section{Bioactive compounds from extracts of FOPF}

Bioactive compounds contained in extracts from FOPF can be known through maceration method with multilevel extraction. This is based on multilevel extraction can separate the bioactive compounds contained in the extract from the FOPF in the same sample based on their level of polarity without the bioactive compounds dissolving in other solvents, therefore in this study the multilevel extraction process starts from a non-polar solvent (n-hexane) followed by a semi-polar solvent (ethyl acetate) and finally with a polar solvent (methanol).

Table 3 shows $n$ acetate extracts FOPF produce the lowest yields ranging from $0.78-1.08 \%$ while the methanol extract produces the largest yields ranging from $5.79-7.87 \%$. The same results were reported by Salamah et al. [18] the lowest yield of Taiwanese gravestone extract was from nhexane extract $(0.04 \%)$ and the highest yield was from methanol extract $(0.12 \%)$.

FOPF which was extracted with methanol, produced the highest yield of $7.87 \%$ of crude compounds. This shows that the most bioactive compounds found in FOPF are polar because they can dissolve in polar solvents namely methanol. Bioactive compounds of FOPF which are non-polar and semi-polar in smaller amounts. Phytochemical analysis of bioactive compounds of extract of fermented oil palm fronds is shown in Table 4.

The extraction process uses methanol solvents in treatments A and C, produce small amounts of tannin and phenolic compounds (+). Sufficient amounts of phenolic compounds (++) were found in treatment $\mathrm{B}$ and $\mathrm{D}$. $\mathrm{N}$ hexane extract in treatment A produced the lowest yield $(0.78 \%)$ and methanol extract produced the highest yield (7.87\%). This shows that treatment A contains polar compounds (methanol) which are greater than non-polar compounds (n hexane). Analysis of phytochemical compounds shows, treatment A contains bioactive compounds, are steroids and tannins, in small amounts (+) and phenolic compounds in sufficient quantities $(++)$.

\section{a. Steroid}

Steroids are initially considered only as components of animal substances (as sex hormones, adrenal hormones, bile acids, etc.), but recently steroids have also been found in plant substances [19]. Steroids contained in methanol extract, ethyl
Table 3. The yield of extracts FOPF

\begin{tabular}{cccc}
\hline \multirow{2}{*}{ Treatment } & \multicolumn{3}{c}{ Yield of extracts (\%) } \\
\cline { 2 - 4 } & N hexane & Ethyl Acetate & Methanol \\
\hline A & 0.78 & 1.53 & 7.87 \\
B & 1.08 & 1.3 & 7.07 \\
C & 1.02 & 1.17 & 5.79 \\
D & 0.89 & 1.08 & 7.4 \\
\hline
\end{tabular}

Note: $\mathrm{A}=$ FOPF with the addition of poultry manure

$\mathrm{B}=\mathrm{FOPF}$ with the addition of cow feces

$\mathrm{C}=\mathrm{FOPF}$ with the addition of urea

$\mathrm{D}=$ FOPF with the addition of molasses

a, b, and c mean with different superscript differ $(\mathrm{p}<0.05)$

acetate and $\mathrm{n}$ hexane in treatment $\mathrm{A}$ are thought to be adrenal hormones and sex hormones, because in poultry, metabolic waste that cannot be used again is released as excreta through cloaca. Excreta consists of feces, urine and sperm/egg cells. Bose et al. [20] stated that steroid compounds were detected in Achatina fulica (freshwater gastropods such as golden snails). Steroids are thought to increase body stamina (aphrodisiac) and anti-inflammation. Silva et al. [21] reported extracts from the leaves of Agave attenuate, containing steroid compounds that have anti-inflammatory activity.

Phytochemical analysis showed that bioactive steroid compounds were detected in all extract of FOPF (n hexane, ethyl acetate and methanol) which had different polarity. Harbone [19] states, steroids are cholesterol, which are non-polar so they can dissolve in non-polar solvents, (n-hexane), semi-polar (ethyl acetate) and polar (methanol) in small amounts (+). The steroid content in beef, which is extracted using non-polar and polar compounds, shows no difference [22].

Bioactive compounds of steroid, which are found in extract of FOPF can be used as antimicrobials because steroids are bioactive compounds that function as anti-fungal. $\mathrm{N}$ hexane extract from lotus seeds contains bioactive steroid compounds and can inhibit the growth of Gram-negative bacteria (Aeromonas hydrophila) and Gram-positive bacteria (Streptococcus agalactiae) and fungi (Saprolegnia sp.) [23].

\section{b. Tannin \\ Methanol extract from FOPF in treatments A}


Table 4. Bioactive compounds of extract of FOPF

\begin{tabular}{ccccccccccccc}
\hline Class of & \multicolumn{4}{c}{ n hexane } & \multicolumn{4}{c}{ Ethyl Acetate } & \multicolumn{3}{c}{ Methanol } \\
\cline { 2 - 11 } Compounds & A & B & C & D & A & B & C & D & A & B & C & D \\
\hline Alkaloid & - & - & - & - & - & - & - & - & - & - & - & - \\
Steroid & + & + & + & + & + & + & + & + & + & + & + & + \\
Terpenoid & - & - & - & - & - & - & - & - & - & - & - & - \\
Flavonoid & - & - & - & - & - & - & - & - & - & - & - & - \\
Saponin & - & - & - & - & - & - & - & - & - & - & - & - \\
Quinone & - & - & - & - & - & - & - & - & - & - & - & - \\
Tannin & - & - & & - & - & - & - & - & + & - & + & - \\
Coumarin & - & - & - & - & - & - & - & - & - & - & - & - \\
Phenolic & - & - & - & - & - & - & - & - & + & ++ & + & ++ \\
\hline
\end{tabular}

Table 2. The effect of different additive on fiber fraction of FOPF

\begin{tabular}{|c|c|c|c|c|c|c|c|c|c|}
\hline \multirow{3}{*}{\multicolumn{2}{|c|}{ Concentration }} & \multicolumn{8}{|c|}{ Inhibited Zone (mm) } \\
\hline & & \multicolumn{4}{|c|}{ E. coli } & \multicolumn{4}{|c|}{ S. aureus } \\
\hline & & A & B & C & $\mathrm{D}$ & A & B & C & $\mathrm{D}$ \\
\hline & $1 \%$ & 12.83 & 9 & 9 & 7.67 & 8 & 7.67 & 11.33 & 6.3 \\
\hline & $2 \%$ & 11.67 & 8.67 & 8.83 & 7.33 & 9.16 & 8.67 & 10.16 & 7.67 \\
\hline & $3 \%$ & 10.5 & 8.66 & 9 & 7.5 & 9.67 & 8 & 10.16 & 9.16 \\
\hline & $4 \%$ & 8.5 & 10.33 & 8 & 8 & 7.83 & 9.33 & 8 & 11.67 \\
\hline & $5 \%$ & 7.33 & 9 & 8.83 & 7.5 & 7.83 & 6.67 & 9 & 10 \\
\hline \multirow{6}{*}{\multicolumn{10}{|c|}{ 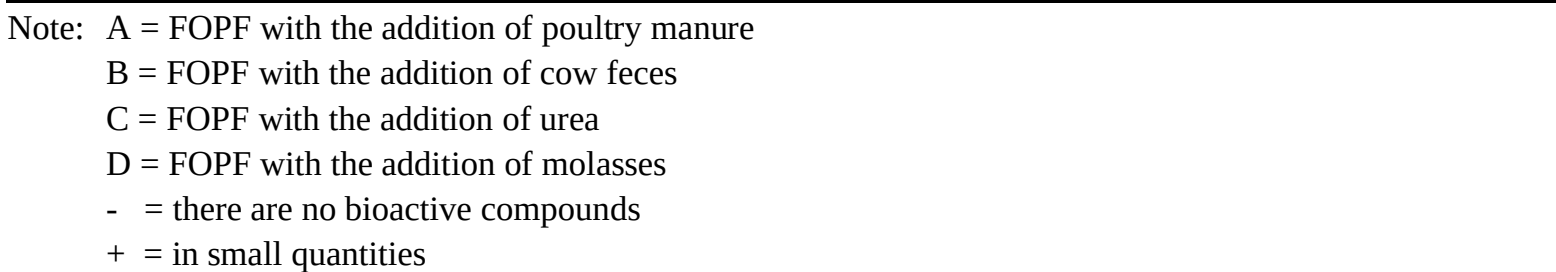 }} \\
\hline & & & & & & & & & \\
\hline & & & & & & & & & \\
\hline & & & & & & & & & \\
\hline & & & & & & & & & \\
\hline & & & & & & & & & \\
\hline & $++=$ there & sufficie & 1 & & & & & & \\
\hline
\end{tabular}

and C contains small amounts of tannin compounds $(+)$. The tannin compounds found in oil palm plants are reported by Sasidharan [7] in methanol extract of palm oil leaves; Febrina et al. [6] on the ethanol extract of oil palm fronds.

The presence of tannin compounds in methanol extract in treatments $\mathrm{A}$ and $\mathrm{C}$ shows that methanol extract from FOPF has the potential to be antimicrobial. Tannin has antibacterial properties by precipitation proteins because it is suspected that tannins have the same effect as phenolic compounds [24]. The tannin compounds found in the ethanol extracts of oil palm fronds [7] and mangosteen peel [25] have the potential to be antimicrobial because they can inhibit the growth of $S$. aureus and E. coli.

\section{c. Phenolic}

Phytochemical analysis in treatment B and D showed that sufficient quantities of phenolic bioactive compounds $(++)$. This indicates that the ex- tract of oil palm frond which is fermented with cow feces and molasses can be used as an antimicrobial. Phenol compounds can be used as antibacterial because they contain aromatic rings with one or two hydroxyl groups that can change the permeability of the cytoplasmic membrane thus inhibiting bacterial growth $[19,26]$. Ethyl acetate extract of binahong leaves, containing polyphenols and saponins with the minimum inhibitory concentration (MIC) against Shigella flexneri was $8 \% \mathrm{~b} / \mathrm{v}[27]$.

\section{Antimicrobial activity test of extracts from FOPF (In Vitro)}

The methanol extract from oil palm fronds which are fermented with different additive has antimicrobial activity which is characterized by the formation of inhibitory zones. The formation of inhibition zones shows that it has inhibited the growth of Gram-positive bacteria (S. aureus) and Gram-negative bacteria (E. coli), by compounds 
contained in methanol extract from FOPF. The inhibitory zone formed shows that bacteria have antimicrobial activity [28], thus it can be concluded that methanol extract from FOPF which are fermented with different sources of additives has antimicrobial activity that is bactericide (killing bacteria).

The inhibitory zone formed in testing the antimicrobial activity of extracts from FOPF in Grampositive (S. aureus) and Gram-negative (E. coli) bacteria at concentrations of $1-5 \%$ as shown in Table 5 .

In Table 5 shown the difference in diameter of inhibition zones in each treatment. The diameter of the inhibition zone ranges from $6.67-12.83$ $\mathrm{mm}$. The smallest diameter inhibition zone of 6.67 $\mathrm{mm}$ was produced at a concentration of $5 \%$ in treatment $\mathrm{B}$. The largest diameter inhibition zone is $12.83 \mathrm{~mm}$ at a concentration of $1 \%$ in treatment A.

The ability of extracts from FOPF inhibits bacterial growth in the moderate to strong, because the diameter of the inhibition zone ranges from 6.67-12.83 $\mathrm{mm}$. In accordance with the statement of Davis and Stout [29] and Mudi and Ibrahim [30] if the diameter of the inhibition zone is more than $6 \mathrm{~mm}$, the extract has antimicrobial activity with a moderate to strong category.

Table 5 shows the diameter of the inhibitory zone in Gram-negative bacteria (E. coli) generally greater than the Gram-positive bacteria ( $S$. aureus). The largest diameter of the inhibition zone in Gram-negative bacteria (E. coli) namely in treatment A with a concentration of $1 \%$ was 12.83 $\mathrm{mm}$. The largest diameter of the inhibition zone in Gram-positive bacteria (S. aureus) namely in treatment $\mathrm{D}$ with a concentration of $4 \%$ is 11.67 $\mathrm{mm}$. There was a difference in the diameter of the inhibitory zone in gram positive and Gram-negative bacteria due to differences in the structure of bacterial cell walls. The data in Table 5 shows that the antibacterial compounds of the methanol extract of FOPF were able to inhibit the growth of Gram-negative bacteria better than Gram-positive bacteria which was characterized by a larger diameter of the inhibition zone. Cell walls of Grampositive bacteria have a simple structure compared to Gram-negative bacteria that have complex structures. The largest diameter inhibition zone $(12.83 \mathrm{~mm})$ for gram negative bacteria (E. coli) showed that the compounds contained in the methanol extract of FOPF had a greater ability to penetrate the cell walls of Gram-negative bacteria. This is because Gram-negative bacteria have a more complex structure and have more layers so that only certain compounds can penetrate it.

The minimum inhibition concentration (MIC) shows the lowest concentration of extract which can inhibit bacterial growth. The smaller the MIC value the greater the antimicrobial activity. This can be seen in treatment $\mathrm{A}$ at a concentration of $1 \%$ which was able to inhibit the growth of pathogenic microbes with the largest diameter of inhibition zone $(12.83 \mathrm{~mm})$.

\section{Conclusion}

The conclusion of this research was FOPF with addition of poultry manure provides good nutritional quality and can inhibit the growth of $E$. coli and S. aureus at a concentration of $1 \%$.

\section{Acknowledgment}

Author would like to thank to the Institute for Research and Community Service of the State Islamic University of Sultan Syarif Kasim Riau which funded this study under contract number 1043/R/2017.

\section{References}

1. Febrina D, Jamarun N, Zain M, Khasrad (2016) The effects of $\mathrm{P}, \mathrm{S}$ and Mg supplementation of oil palm fronds fermented by Phanerochaete chrysosporium on rumen fluid characteristics and microbial protein synthesis. Pakistan Journal of Nutrition 15: 299 - 304. doi: doi.org/10.3923/pjn.2016.299.304.

2. Febrina D, Jamarun N, Zain M, Khasrad (2016) Effects of calcium (Ca) and manganese (Mn) supplementation during oil palm frond fermentation by Phanerochaete chrysosporium on in vitro digestibility and rumen fluid characteristics. Pakistan Journal of Nutrition 15: 352 - 358 . doi: doi.org/10.3923/pjn.2016.352.358.

3. Zahari WM, Hassan OA, Wong HK, Liang JB (2003) Utilization of oil palm frond - based diets for beef and dairy production in Malaysia. Asian-Australasian Journal of Animal Sciences 16 (4): 625 - 634. doi: doi.org/10.5713/ajas.2003.625.

4. Rahman MM, Lourenço M, Hassim HA et al. (2011) Improving ruminal degradability of oil palm fronds using white rot fungi. Animal Feed Science and Technology 169 (3-4) :157 - 166. doi: doi.org/10.1016/j.anifeedsci.2011.06.014.

5. Kawamoto H, Mohamed WZ, Sukur NIM et al. (2001) Palatability, digestibility and voluntary intake of processed oil palm 
fronds in cattle. Japan Agricultural Research Quarterly 35; 195 - 200. doi: doi.org/10.6090/jarq.35.195.

6. Febrina D, Febriyanti R, Zam SI et al. (2018) Antibacterial activity testing and ethanol extract characterization of oil palm fronds (Elaeis guineensis Jacq.). Pakistan Journal of Nutrition 17 (9): 427 - 433. doi: 10.3923/pjn.2018.427.433.

7. Sasidharan S, Rajoo N, Rathinam X et al. (2010) Wound healing potential of Elaeis guineensis Jacq. leaves in an infected albino rat model. Molecules 15: 3186 - 3199. doi: 10.3390/molecules15053186.

8. Syahmi ARM, Vijayarathna S, Sasidharan S et al. (2010) Acute oral toxicity and brine shrimp lethality of Elaeis guineensis Jacq. (oil palm leaf) methanol extract. Molecules 15: 8111 8121. doi: 10.3390/molecules15118111.

9. Febrina D (2016) Utilization of oil palm fronds biodelignification products using Phanerochaete chrysosporium as substitute forage on goat. PhD thesis. Andalas University, Department Animal Science.

10. Franswort NR (1996) Biological and phytochemical screenings of plant. Journal of Pharmaceutical Science 55 (3): 225 - 265. doi: 10.1002/jps.2600550302.

11. Handayani D, Sandrawaty N, Murniati M, Regina R (2015) Screening of endophytic bacteria isolated from marine sponge Haliclona fascigera for inhibition against clinical isolates of methicillin resistant Staphylococcus aureus (MRSA). Journal of Applied Pharmaceutical Science 5: 139 - 142. doi 10.7324/JAPS.2015.50926.

12. Ozduven ML, Koc F, Polat C, Coskuntuna L (2009) The effects of lactic acid bacteria and enzyme mixture inoculants on fermentation and nutrient digestibility of sunflower silage. Kafkas Universitesi Veteriner Fakultesi Dergisi 15 (2): 195 - 199. doi: 10.9775/kvfd.2008.91-A.

13. Laura B, Paolo G (2006) Algae: Anatomy Biochemistry and Biotecnology. Boca Raton, CRC Press.

14. Umiyasih U, Wina E (2008) Processing and nutritional value of corn by-product as ruminant feed. Wartazoa 18 (3): 127 - 136.

15. Saun RJV, Henrich AJ (Eds) (2008) Proceedings of the MidAtlantic Conference: 26 May 2008; Pennsylvania. Penn States Collage.

16. Amanullah MA, Sekar S, Muthukrishnan P (2010) Prospect and potential of poultry manure. Asian Journal of Plant Sciences 9 (4): 1 - 11. doi: 10.3923/ajps.2010.172.182.

17. Thambirajah JJ, Zulkali MD, Hashim MA (1995) Microbiological and biochemical changes during the composting of oil palm empty-fruit-bunches. Effect of nitrogen supplementation on the substrate. Bioresource Technology 52 (2): 133 - 144. doi 10.1016/0960-8524(95)00008-3.
18. Salamah E, Ayuningrat E, Purwaningsih S (2008) Initial screening of freshwater mussel bioactive components from (Anodonta woodiana Lea.) from antioxidant compounds. Buletin Teknologi Hasil Perikanan 11 (2): 119 - 132. doi: 10.17844/jphpi.v11i2.912.

19. Harborne AJ. Phytochemical Methods A Guide to Modern Techniques of Plant Analysis. 3rd Edition. Dordrecht, Springer.

20. Bose R, Majumdar C, Bhattacharya S (1997) Steroids in Achatina fulica (bowdich): Steroid profile in haemolymph and in vitro release of steroids from endogenous precursors by ovotestis and albumen gland. Comparative Biochemistry and Physiology 116 (3): 179 - 182. doi: 10.1016/S0742-8413(96)00163-6.

21. Silva BP, Sousa AC, Silva GM, Mendes TP, Parente JP. A new bioactive steroidal saponin from Agave attenuata. Zeitschrift für Naturforschung 57c: $423-428$.

22. Schmidt G, Steinhart H (2001) Impact of extraction solvents on steroid contents determined in beef. Food Chemistry 76 (1): 83 - 88. doi: 10.1016/S0308-8146(01)00237-0.

23. Widya DR, Suryanto D, Desrita (2014) Antimicrobial activity of lotus seeds (Nymphaea pubescens L.) on bacteria Aeromonas hydrophila, Streptococcus agalactiae, and Saprolegnia sp. Jurnal Aquacoastmarine 2 (1): 7 - 14

24. Martono B, Setiyono RT (2014) Phytochemical screening of six tea genotypes. Journal of Industrial and Baverage Crops 1 (2): 63 - 68. doi: 10.21082/jtidp.v1n2.2014.p63-68.

25. Poelongan M, Praptiwi (2010) Antibacterial activity test of mangos teen (Gardnia mangostana Linn.) peel. Media Litbang Kesehatan 20 (2): 65 - 69.

26. Ikalinus R, Widyastuti SK, Setiasih NLE (2015) Phytochemical screening ethanol extract skin stem moringa (Moringa oleifera). Indonesia Medicus Veterinus 4 (1): 71 - 79.

27. Wardhani LK, Sulistyani N (2012) Antibacterial activity test of ethyl acetate extract of binahong leaf (Anredera scandens (L.) Moq.) against Shigella flexneri with the profile of thin layer chromatography. Jurnal Ilmiah Kefarmasian 2 (1): 1 - 16.

28. Nanda. A, Saravanan M (2009) Biosynthesis of silver nanoparticles from Staphylococcus aureus and its antimicrobial activity against MRSA and MRSE. Nanomedicine: Nanotechnology, Biology and Medicine 5 (4): 452 - 456. doi: 10.1016/j.nano.2009.01.012.

29. Davis WW, Stout TR (1971) Disc plate method of microbiological antibiotic assay. I. Factors influencing variability and error. Applied Microbiology 22: 659 - 665.

30. Mudi SY, Ibrahim H (2008) Activity of Bryophyllum pinnatum S. Kurz extracts on respiratory tract pathogenic bacteria. Bayero Journal of Pure Applied Sciences 1 (1): 43 - 48. doi: 10.4314/bajopas.v1i1.57512. 
This page is intentionally left blank. 